\title{
KARAKTERISTIK UMUM DIATOM DAN APLIKASINYA PADA BIDANG GEOSAINS
}

\author{
Oleh \\ Septriono Hari Nugroho ${ }^{1)}$
}

\begin{abstract}
AN OVERVIEW OF DIATOM AND ITS APPLICATIONS ON THE GEOSCIENCE AREA. Diatoms have been being studied in many countries. Diatoms provide a valuable and well-understood means on biomonitoring-one of which is focused on the base of the aquatic foodweb and highly representative of water quality. They are found in most aquatic environments and the systematic and taxonomic investigations of modern and fossil diatoms have been supported by numerous studies of distributional ecology. Diatom systematics, taxonomy and ecology indeed offer a wide scope of applications - from water quality to environmental monitoring and biostratigraphy as well as on geoscience area. The application of diatom analysis in determining whether drowning was the cause of death has proven to be a valuable tool in forensic science. Furthermore, diatoms can provide a record of environmental conditions because their relationship to water quality and aquatic habitat has been already known, and the diatom cell wall, which is silicified to form a frustule, is well-preserved, easily detectable and occurs in high numbers in sediment and water. However, this should not be limited to simply make an inventory of data: thoughtful ecology and paleo-ecology will assist in predicting the environmental impact of pollution and climate changes.
\end{abstract}

\section{PENDAHULUAN}

Plankton masih dianggap oleh sebagian besar masyarakat sebagai makanan paus dan hewan laut besar lainnya. Sebuah studi global selama empat tahun menemukan, bahwa plankton merupakan sumber oksigen di bumi (Putic, 2015). Plankton adalah binatang, ganggang, bakteri dan organisme mikroskopis lainnya yang tidak kasat mata. Mereka mendiami lapisan-lapisan permukaan samudera, laut dan perairan tawar di dunia. Salah satu plankton yang mendominasi perairan tawar dan laut adalah diatom, yaitu lebih dari 260

1) Pusat Penelitian Laut Dalam, LIPI genus diatom hidup dengan lebih dari 100.000 spesies (Round et al., 1990). Namun, menurut Nontji (2008), di dunia ini diperkiriakan ada sekitar 1.400-1.800 jenis diatom, tetapi tidak semua hidup sebagai plankton.

Diatom berasal dari kata Yunani "Diatomos" yang berarti dipotong setengah. Saat ini diketahui diatom memiliki struktur khas yaitu dinding sel terbagi menjadi dua bagian yang dilapisi oleh silika. Diatom merupakan fitoplankton yang berperan sebesar $25 \%$ dalam proses fotosintesis di bumi, asalkan tersedia cahaya dan nutrisi yang 
cukup. Selain itu, diatom mempunyai konstribusi $40-45 \%$ dalam produktivitas laut, sehingga lebih produktif, jika dibandingkan dengan hutan hujan di seluruh dunia. Diatom berfotosintesis di laut menghasilkan karbon organik yang berfungsi sebagai dasar untuk jaring makanan di laut. Jadi tidak mengherankan diatom berperan penting dalam siklus silika dan karbon di alam sehingga kesinambungan perikanan terjaga (Mann, 1999). Diatom mempunyai keunikan dan sangat spesifik, karena arsitektur dan anatomi dinding selnya yang tersusun dari silika, sehingga dapat tersimpan dalam kurun waktu yang sangat lama di dalam sedimen (Soeprobowati \& Suwarno, 2009).

\section{PERKEMBANGAN STUDI DIATOM}

Penelitian diatom berkembang sangat pesat dimulai tahun 1703, ketika mikroskop ditemukan, hingga ketika Battarbee (1986) menyatakan potensi diatom sebagai bioindikator kualitas lingkungan. Sejak tahun 1990an penelitian tentang diatom sebagai bioindikator kualitas perairan banyak dilakukan di berbagai negara sampai aplikasinya dalam paleorekonstruksi perubahan lingkungan. Hal ini seiring dengan perkembangan implementasi analisis statistik multivariat untuk analisis paleorekonstruksi (Smol, 1990).

Pada tahun 1904 Gregory Popp menjadi ilmuwan pertama yang hadir di pengadilan kasus, ketika geologi digunakan untuk bahan hukuman pidana (Ruffell \& McKinley, 2005). Tidak sampai tahun 1975, buku teks pertama tentang geologi forensik diterbitkan (Murray \& Tedrow, 1975), dan ada beberapa literatur di lapangan yang terbatas (Saferstein, 2001; Murray, 2004; Pye \& Croft 2004; Ruffell \& McKinley, 2005; Ruffell, 2006). Banyak teks umum tentang investigasi TKP (Tempat Kejadian Perkara) menyebutkan sedikit atau tidak sama sekali tentang geologi forensik (Saferstein, 2001) dan masih kurangnya pengetahuan dalam profesi hukum dan kekuatan polisi dari kalangan ahli geologi (Pye \& Croft, 2004; White, 2004). Namun, salah satu teknik forensik berbasis geologis yang telah menjadi mapan dalam ilmu forensik adalah "tes diatom" untuk kasus tenggelam (Peabody \& Burgess, 1984; Pollanen, 1998; Cameron, 2004; Horton et al., 2006; Wilianto, 2012).

\section{MORFOLOGI DIATOM}

Diatom merupakan jenis alga yang termasuk ke dalam Kelas Bacillariophyceae. Diatom dapat dibedakan dengan alga lainnya adalah material penyusun dinding sel yang tersusun oleh silika, sehingga dapat terpreservasi dengan baik pada sedimen. Diatom berasal dari kata "di atom" atau memiliki dua bagian, bagian yang satu menutupi yang lainnya (Taylor et al., 2007). Pigmen diatom yang berwarna kuning lebih banyak daripada pigmen hijau, membuat diatom disebut juga sebagai golden brown algae. Pigmen tersebut menjadikan perairan yang terdapat diatom di dalamnya akan terlihat berwarna agak cokelat muda. 
Diatom merupakan organisme sel tunggal (uniseluler) yang hidup secara soliter dan pada beberapa spesies hidup secara berkoloni (Gambar 1) (Kale \& Karthick, 2015). Diatom dilapisi oleh dinding keras yang terbentuk dari pektin yang berisi silika yang disebut frustule. Frustule tersebut terdiri dari epiteka (katup bagian atas) dan hipoteka (katup bagian bawah). Epiteka berukuran lebih besar dan lebih tua dibandingkan hipoteka dan memiliki elemen pengikat yang disebut cingulum. Chloroplast digunakan untuk melakukan fotosintesis dengan pigmen kuning. Lipid droplet merupakan produk yang dihasilkan berupa zat minyak sebagai tempat penyimpanan produk fotosintesis. Nucleus merupakan inti sel diatom, diatom merupakan organisme eukariotik yang inti sel-nya diselimuti oleh membran sel. Vacuole merupakan bagian yang berfungsi sebagai pengatur pusat koordinasi diatom (Taylor et al., 2007).

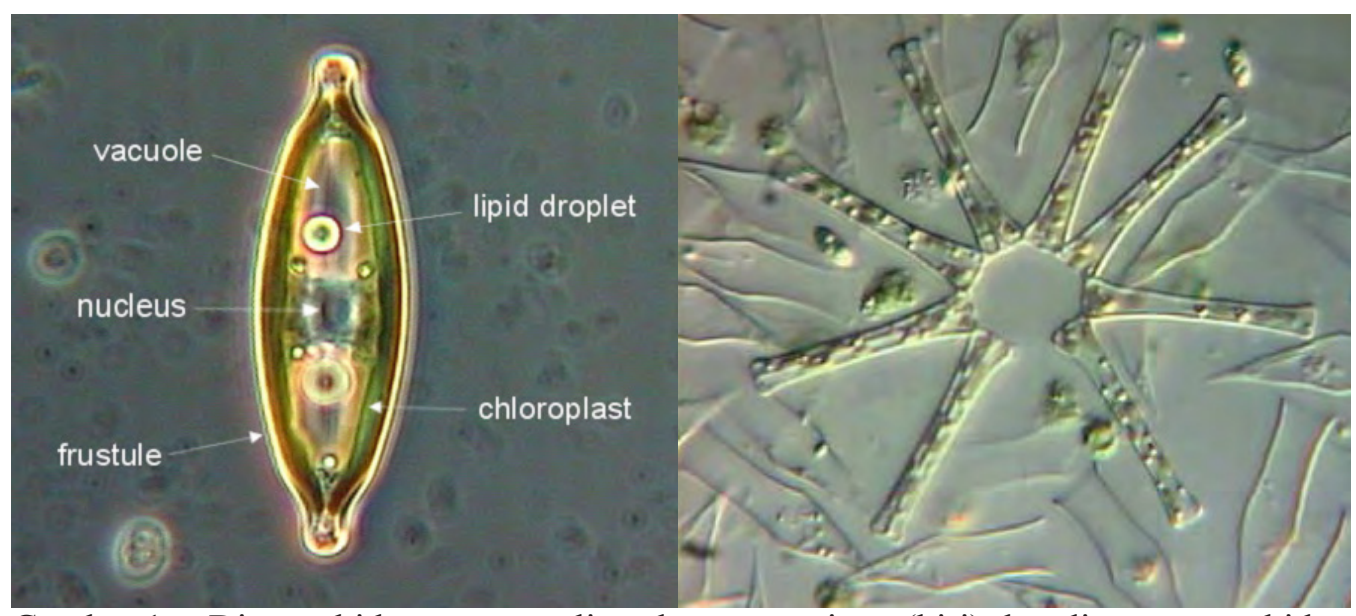

Gambar 1. Diatom hidup secara soliter dan anatominya (kiri) dan diatom yang hidup berkoloni (kanan) (Taylor et al., 2007).

Secara umum terdapat dua jenis diatom yang dibedakan berdasarkan ciri morfologinya, yaitu diatom centric berbentuk bulat, yang hidup secara planktonik dan diatom pennate yang hidup secara bentik (Gambar 2). 


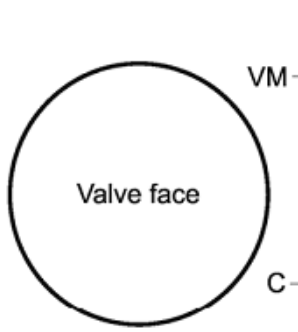

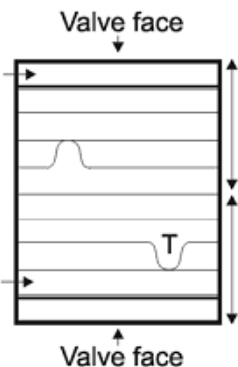

Girdle view

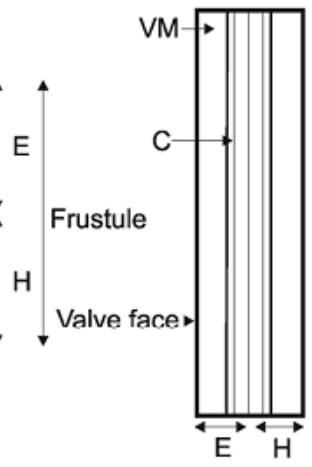

Girdle view Valve view

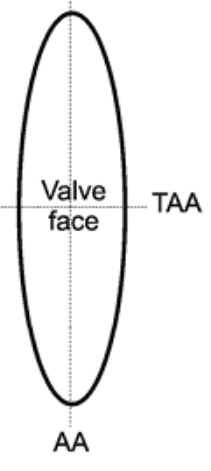

Gambar 2. Morfologi diatom (Taylor et al., 2007).

Diatom sentrik (centric) bercirikan bentuk sel yang mempunyai simetri radial atau konsentrik dengan satu titik pusat, dan biasanya hidup secara planktonik. Selnya dapat berbentuk bulat (misalnya, gambar 3a), lonjong, silindris (misalnya, Gambar $3 b)$, dengan penampang bulat, segitiga atau segiempat. Sebaliknya, diatom penat (pinnate) mempunyai simetri bilateral, yang bentuknya umumnya memanjang atau berbentuk sigmoid, seperti huruf "S", biasanya hidup secara bentik. Beberapa fitur umum dalam diatom penat dapat dilihat di Gambar 4.
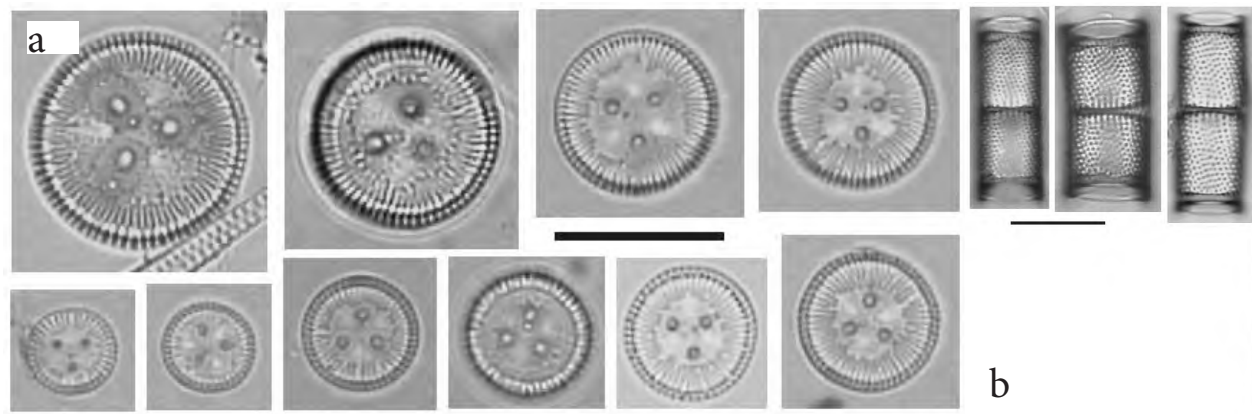

b

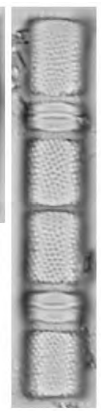

Gambar 3. Contoh diatom sentris. a. Cyclotella ocellata Pantocsek berbentuk bulat, b. Aulacoseira ambigua (Grunow) Simonsen berbentuk silindris (Taylor et al., 2007). 


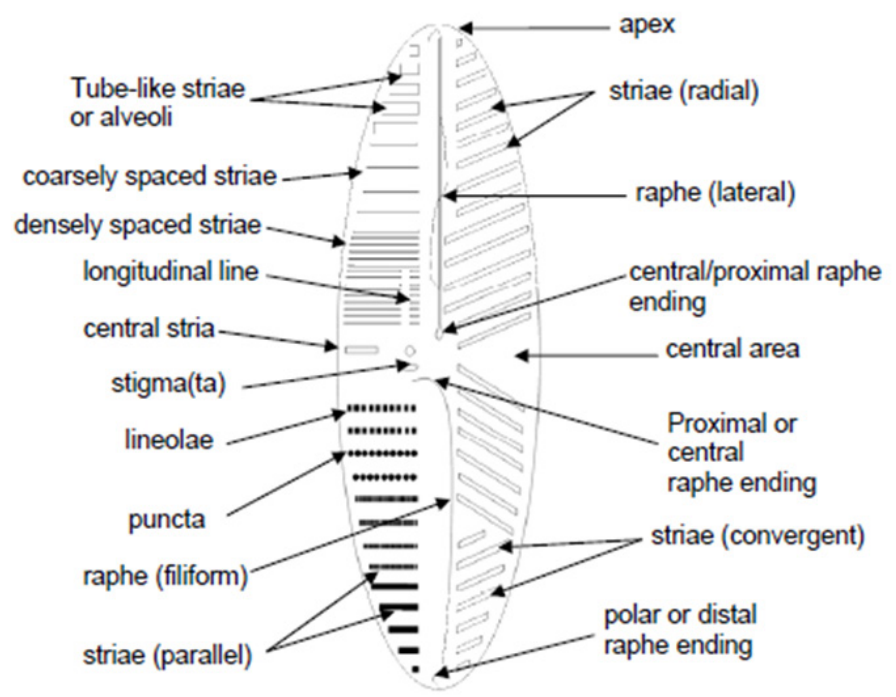

Gambar 4. Fitur umum yang terdapat dalam diatom penat (Taylor et al., 2007).

Sepanjang median sel diatom penat ada jalur tengah yang disebut raphe (Nontji, 2008). Raphe pada diatom digunakan untuk pergerakan diatom yang juga penting dalam identifikasi dan berfungsi untuk bergerak dengan mengeluarkan semacam cairan. Berdasarkan jenis raphe yang dimiliki, diatom dibedakan menjadi (1) araphideae tidak memilik raphe, atau disebut juga pseudoraphe, (2) raphidiodeae memiliki raphe pada ujung tubuhnya, atau disebut juga eunotia raphe, (3) monoraphideae memiliki raphe hanya pada satu bagian tubuhnya, atau disebut juga pseudoraphe dan (4) biraphideae memiliki raphe pada dua bagian tubuhnya yang terbagi menjadi dua jenis yaitu median raphe dengan raphe terletak di tengah tubuhnya dan canal raphe dengan raphe terletak di samping tubuhnya (Gambar 5). Namun, ada juga yang tidak memiliki sistem raphe yang jelas (Gambar 6).

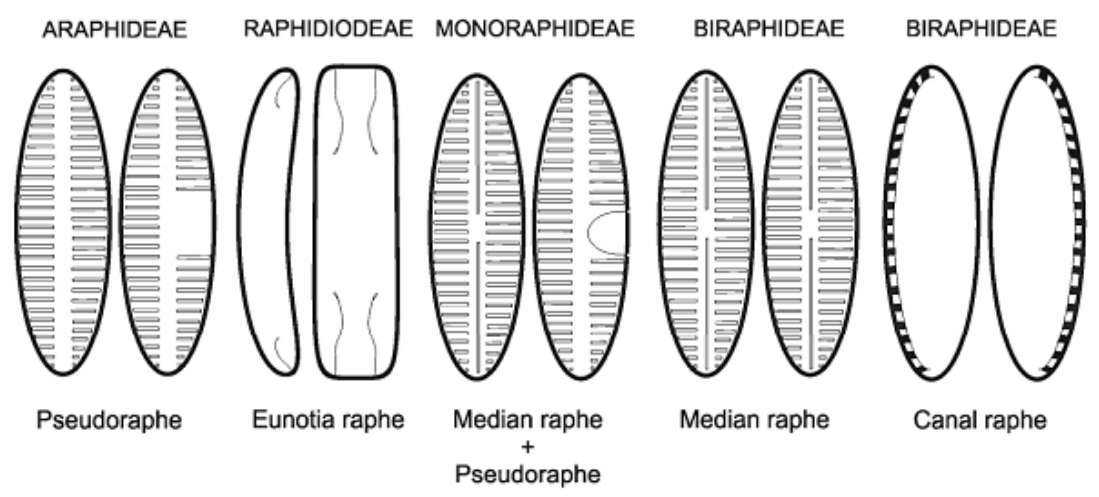

Gambar 5. Pembagian jenis pennate berdasarkan karakteristik raphe (Taylor et al., 2007). 


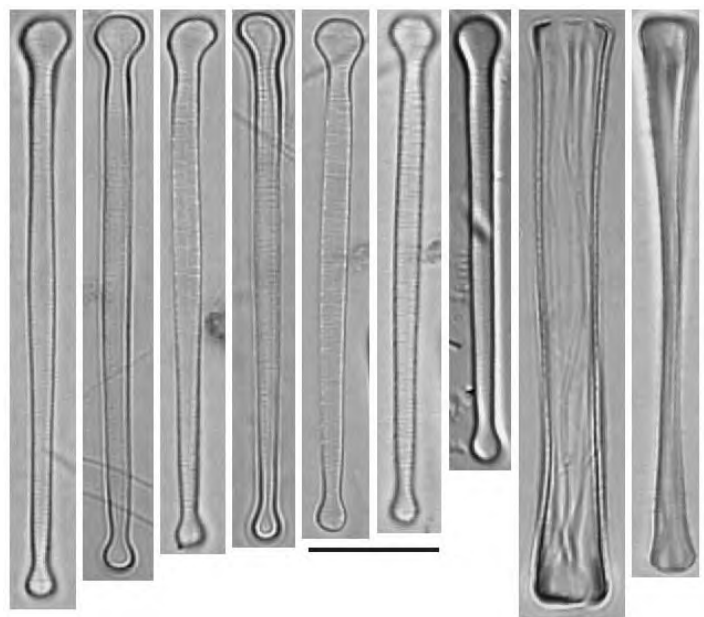

Gambar 6. Asterionella formosa Hassal merupakan contoh diatom yang tidak memiliki sistem raphe yang jelas (Taylor et al., 2007).

Bold \& Wyne (1985) perlahan-lahan dari partikel-partikel di menjelaskan bahwa diatom pennate bergerak secara spontan. Pergerakan terjadi karena dua hal. Pertama yaitu adanya sekresi rantai mukopolisakarida. Zat ini dikeluarkan secara terus-menerus, sehingga menyebabkan sel bergerak, dan mampu pindah dari satu tempat ke tempat lain. Kedua yaitu adanya mekanisme kapilaritas yang menimbulkan gerakan sepanjang raphe. Ketiga, pergerakan diatom berkaitan erat dengan aliran sitoplasma dalam sel dan keberadaan raphe pada dinding sel. Determinasi diatom juga harus memperhatikan bentukan apex, yaitu bentukan yang terdapat pada ujung tubuhnya yang dibagi menjadi 10 jenis (Gambar 7).

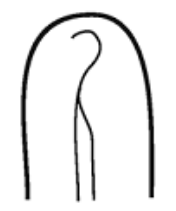

a

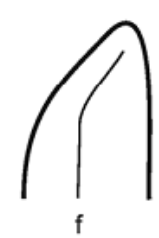

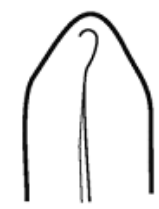

b

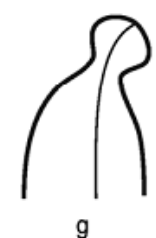

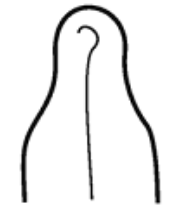

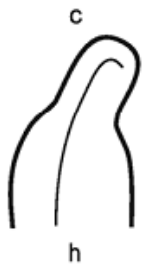

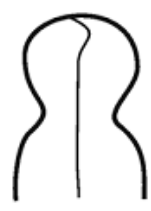

d

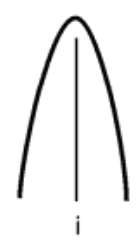

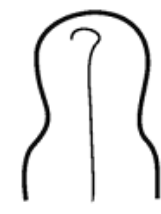

e

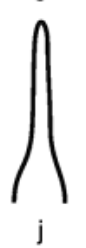

Gambar 7. Bentukan apex diatom. a: rounded, b: cuneate, c: rostrate, d: capitate, e: subcapitate, f: sigmoidly cuneate, g: capitate, h: rostrate, i: acutely, j: elongate (Taylor et al., 2007). 


\section{EKOLOGI DIATOM}

Berdasarkan ekologinya, diatom dapat di kelompokkan menjadi diatom asli parairan tersebut (Autochthonous), dan diatom yang berasal dari luar perairan (Allochthonous). Pada daerah-daerah pantai atau estuari yang banyak terdapat vegetasi, seperti lamun (seagrass) dan makroalga, kebanyakan dijumpai kelompok diatom asli (autochthonous) yang umumnya berasal dari epiphyte yang melekat pada macrophyte. Penggolongan diatom berdasarkan ekologi dan habitatnya disajikan dalam tabel 1 .

Tabel 1. Penggolongan diatom berdasarkan ekologi (Kasim, 2008).

\begin{tabular}{|l|l|}
\hline \multicolumn{1}{|c|}{ Ekologi } & \multicolumn{1}{|c|}{ Jenis diatom } \\
\hline Melekat pada tumbuhan lain yang lebih besar. & Epiphytic \\
\hline Hidup dan tumbuh pada pasir & Epipsamic \\
\hline $\begin{array}{l}\text { Hidup dan tumbuh pada permukaan tanah liat } \\
(\text { mud } \text { atau sediment }\end{array}$ & Epipelic \\
\hline $\begin{array}{l}\text { Tumbuh dalam rongga tanah liat (mud) atau } \\
\text { sedimen }\end{array}$ & Endopelic \\
\hline Tumbuh dan melakat pada permukaan batuan & Epilithic \\
\hline $\begin{array}{l}\text { Tumbuh di dalam rongga batuan pada dasar } \\
\text { perairan }\end{array}$ & Endolithic \\
\hline $\begin{array}{l}\text { Melekat pada hewan umumya invertebrata } \\
\text { dasar perairan }\end{array}$ & Epizoic \\
\hline $\begin{array}{l}\text { Melekat pada benda-benda yang keras yang } \\
\text { biasannya ditanam atau diletakkan pada dasar } \\
\text { perairan }\end{array}$ & Fouling \\
\hline
\end{tabular}

Diatom tersebar pada seluruh perairan dunia, dari perairan tawar hingga laut dalam (Gambar 8). Diatom hidup terapung bebas di dalam badan air dan kebanyakan melekat pada substrat yang lebih keras. Pelekatan diatom biasanya karena tumbuhan ini mempunyai semacam gelatin (gelatinous extrusion) yang memberikan daya lekat pada benda atau substrat. Kadang ditemukan beberapa diatom yang walau sangat lambat tetapi punya daya untuk bergerak. Diatom akan sangat tergantung pada pola arus dan pergerakan massa air baik itu secara horizontal maupun vertikal (Kasim, 2008). Ada diatom yang hidup sebagai bentos (di dasar laut) atau yang kehidupan normalnya di dasar laut tetapi oleh gerakan adukan air dapat membuatnya lepas dari dasar dan terbawa hanyut sebagai plankton (disebut sebagai tikoplankton) (Nontji, 2008). Faktor 
lingkungan, seperti perbedaan suhu dan makanan pada perairan berpengaruh besar terhadap keberadaan dan struktur morfologi diatom (Pappas \& Stroemer, 2003).

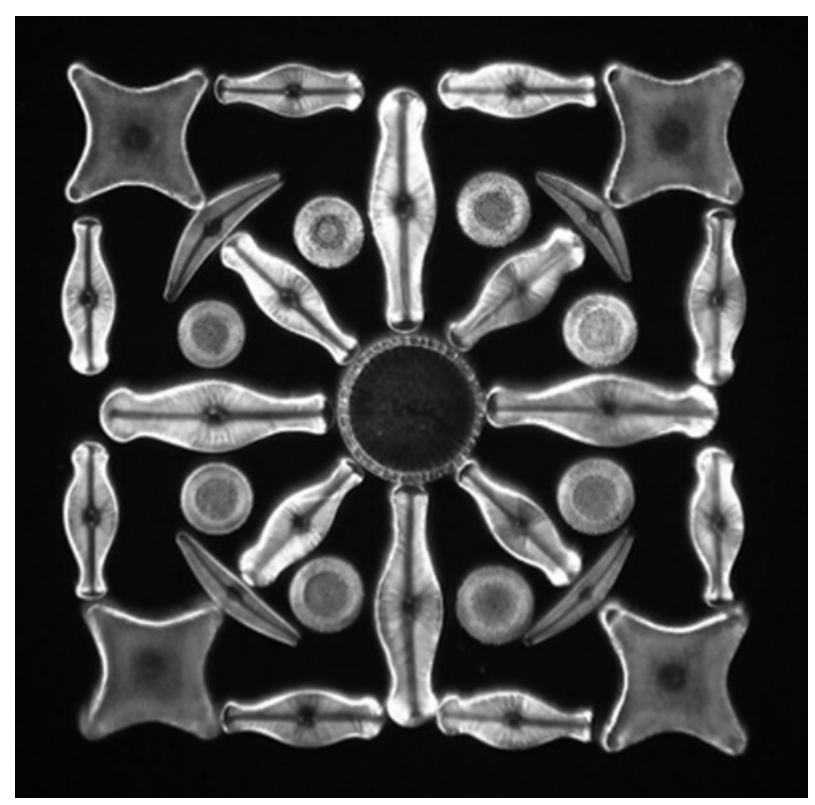

Gambar 8. Jenis-jenis diatom yang berasal dari perairan tawar dan laut (Nagy, 2011).

Sumber kesalahan umum adalah ketika dalam menyimpulkan kondisi ekologis dengan menggunakan komunitas diatom, muncul dari pengambilan sampel dari substrat yang tidak terjajah (Taylor et al, 2007). Komunitas diatom dapat dideteksi pada substrat dengan perasaan (berlendir) atau dapat dilihat seperti selaput tipis berwarna coklat keemasan yang menutupi substrat (Gambar 9). Dalam beberapa kondisi atau pada waktu-waktu tertentu (dalam setahun) selaput ini mungkin menjadi lebih tebal dan lebih terlihat. Mikrohabitat alami yang penting adalah substrat padat, sedimen basah yang terpapar dan batang pohon yang berakar (Taylor et al., 2007; Aiyer \& Reddy, 2013). Diatom juga terdapat dalam seston atau komponen fitoplankton yang mengambang. Benda buatan manusia dan benda lain (kertas atau kantong plastik, potongan kayu) juga sering dijajah oleh diatom (Taylor et al., 2007; Aiyer \& Reddy, 2013). 

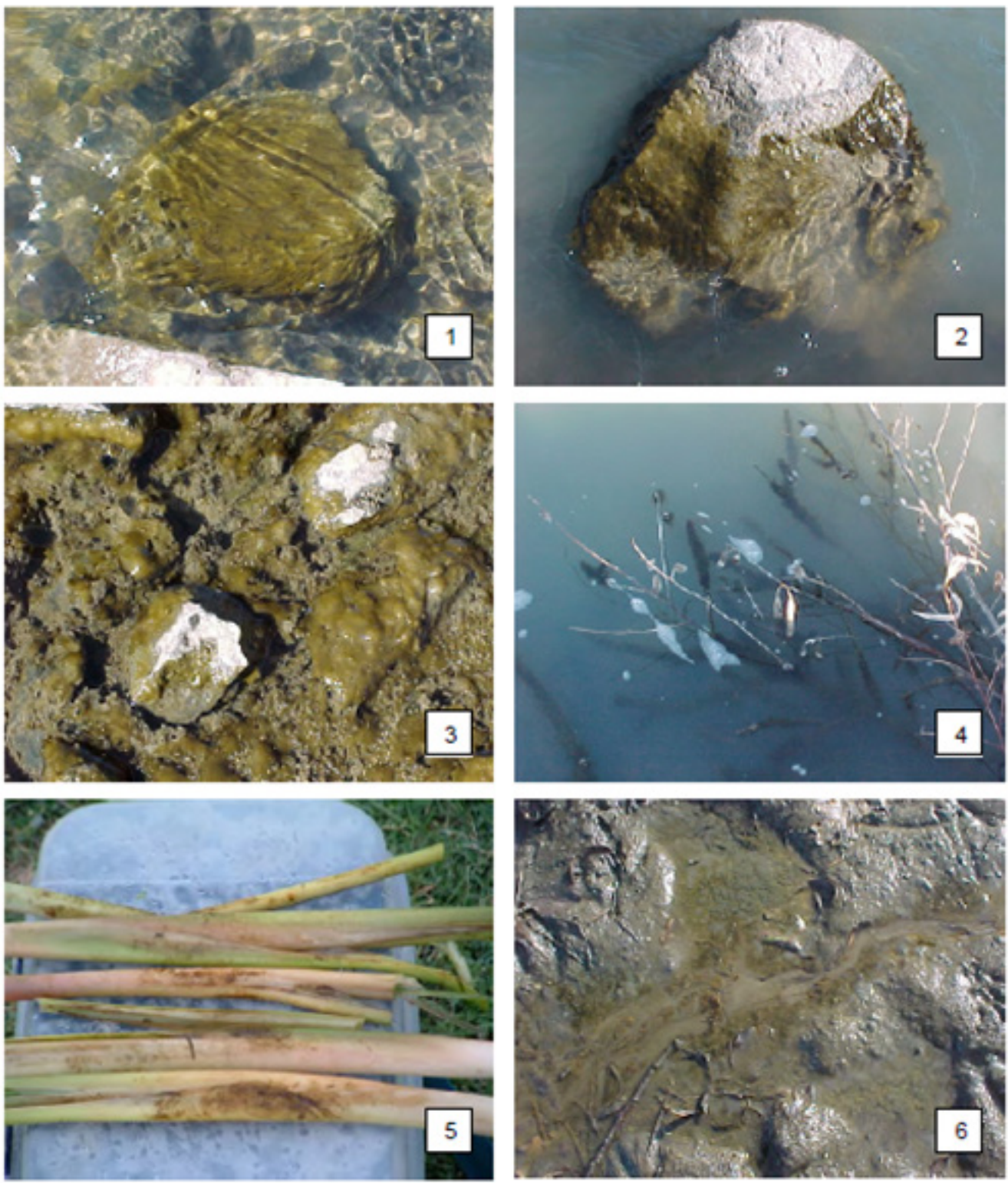

Gambar 9. Kondisi ekologi diatom. Bagian $1 \& 2$ menunjukkan lapisan tebal sel diatom yang menempel pada batu besar. Bagian 3 menunjukkan lapisan diatom yang berkembang diantara sedimen dan kerikil. Bagian 4 menunjukkan diatom tumbuh dengan lebat di sekitar cabang pohon yang tenggelam. Bagian 5 menunjukkan selaput diatom dapat ditemukan di batang Phragmites australis yang terendam. Bagian 6 menunjukkan diatom yang mendiami sedimen (Taylor et al., 2007). 


\section{FAKTOR-FAKTOR YANG MEMPENGARUHI PERTUMBUHAN DIATOM}

Ekosistem perairan dapat
dipengaruhi oleh berbagai faktor lingkungan, baik faktor fisik maupun kimia. Faktor fisik dapat berupa suhu, $\mathrm{pH}$, dan kecepatan arus, sedangkan faktor kimia dapat berupa kandungan unsur hara dalam perairan (Sari et al., 2013). Air merupakan hal yang penting untuk pertumbuhan dan perkembangan, serta diperlukan pada berbagai macam proses kehidupan diatom. Bila tidak ada air, diatom tidak akan mampu bertahan hidup lebih lama dalam keadaan aktif. Cahaya juga termasuk faktor penting yang ikut menentukan fotosintesis, pertumbuhan dan perkembangan diatom. Ada jenis diatom yang tidak peka terhadap intensitas cahaya. Namun, ada juga yang dalam proses metabolismenya memerlukan intensitas cahaya tertentu. Oleh karena itu, diperlukan cahaya yang sesuai agar proses tersebut berjalan baik. Tingkat kecerahan (visibilitas) dan intensitas cahaya akan menurun seiring dengan peningktan kedalaman. Kedalaman optimum bagi diatom untuk melakukan fotosintesisi berkisar 5-20 m (Boney, 1975; Wickstead, 1965).

Suhu juga merupakan faktor yang memengaruhi keberadaan diatom dalam habitatnya. Suhu yang tinggi akan memengaruhi proses metabolisme, menaikkan kecepatan perubahan sel, respirasi, dan memengaruhi pergerakan diatom karena adanya perubahan viskositas sitoplasma di dalam raphe. Suhu yang berhubungan dengan factor iklim lainnya merupakan variable yang mengontrol kelimpahan dan distribusi diatom (Weckstrom \& Korhola, 2001; Yuliana, 2007). Chaetoceros merupakan diatom yang bersifat eurythermal dan euryharline (Roito et al., 2014). Diatom ini dapat hidup pada kisaran suhu yang tinggi, pada suhu $400{ }^{\circ} \mathrm{C}$ masih dapat bertahan hidup namun tidak berkembang. Pertumbuhan optimumnya memerlukan suhu pada kisaran antara $25-30{ }^{\circ} \mathrm{C}$

Kandungan senyawa organik yang terlarut dalam perairan sangat berpengaruh terhadap tingkat keasaman dan kebasaan. Beberapa anggota diatom memerlukan $\mathrm{pH}$ di bawah 7,00 dan kandungan kalsium (Ca), serta Magnesium $(\mathrm{Mg})$ yang rendah, misalnya Eunotia dan Frustulia (Siregar \& Telaumbanua, 2010; Harmoko \& Krisnawati, 2018). Genus yang lain justru sebaliknya, menghindari air yang mengandung asam dan konsentrasi kalsium dan magnesium yang sangat rendah, seperti Mastogoia, Diploneis, Amphipleura, Gysigma, Denticula, Ephitemia, dan Rhopalopoada. Perubahan sedikit pada nilai $\mathrm{pH}$ dan senyawa organik perairan akan memengaruhi keberadaan diatom dalam perairan tersebut (Barsanti \& Gualtieri, 2006).

\section{PERANAN DAN APLIKASI PENGGUNAAN DIATOM}

Selama ini peranan diatom yang masyarakat awam ketahui adalah sebagai penghasil oksigen dan bahan organik bagi organisme akuatik, bioindikator kualitas 
perairan, serta diatom yang mengendap di dasar laut dalam rentang waktu yang lama dapat menjadi indikator cadangan minyak bumi. Diatom sebagai bioindikator kualitas perairan memiliki keunggulan dibandingkan organisme lainnya, karena distribusi luas, populasi variatif, penting dalam rantai makanan, siklus hidup pendek, reproduksi cepat, hampir semua terdapat di permukaan substrat, banyak spesies sensitif terhadap perubahan lingkungan, mampu merefleksikan perubahan kualitas air dalam jangka pendek dan panjang, mudah pencuplikan, pengelolaan dan identifikasinya (Gell et al., 1999; Round et al., 1990).

Namun tidak banyak yang mengetahui, bahwa dalam dunia kedokteran forensik melalui tes diatom pada tubuh korban yang diduga meninggal karena tenggelam, keberadaan diatom sangat membantu dalam mengetahui penyebab kematian. Keberadaan diatom pada tubuh korban sebagai alat penting dalam diagnosis, konfirmasi kematian, serta bukti pendukung dalam penyebab kematian (Wilianto, 2012). Analisis diatom dapat digunakan lebih lanjut dalam ilmu forensik melalui mengidentifikasi asalusul individu, pakaian atau bahan dari situs investigasi (Peabody, 1980, 1999; Siver et al., 1994; Pollanen et al. 1997; Krstic et al., 2002 ; Cameron 2004). Jika bahan telah terendam atau ada kontak dengan sedimen atau vegetasi litoral atau riparian, analisis diatom dari sedimen atau jejak diatom lainnya yang terdapat pada pakaian atau alas kaki dapat digunakan untuk mengidentifikasi jenis habitat (Cameron, 2004). Ada gradien lingkungan yang kuat dalam salinitas, $\mathrm{pH}$, dan konsentrasi nutrisi di muara dan sungai, sehingga analisis diatom akan mencerminkan variasi dalam kualitas air (Horton, 2007).

Diatom yang biasa ditemukan pada kasus tenggelam di air tawar, seperti kolam, danau, sungai dan kanal adalah: Navicula pupula, N. cryptocephara, N. graciloides, $N$. meniscus, $N$. bacillum, $N$. radiosa, $N$. simplex, $N$. pusilla, Pinnularia mesolepta, P. gibba, P. braunii, Nitzscia mesplepta, Mastoglia smithioi, Cymbella cistula, Camera lucida, Cymbella cymbiformi, dan Cocconeis diminuta. Pinnularia boreali ditemukan pada air tawar yang dingin, Pinnularia capsoleta ditemukan pada air tawar yang dangkal (Wilianto, 2012). Dari beberapa literatur yang ada dapat disimpulkan bahwa macam-macam spesies dari diatom yang paling sering ditemukan pada organ-organ tubuh manusia yang diduga meninggal karena tenggelam. Tabel 2 merupakan rangkuman dari spesies diatom yang sering di temukan di dalam organ tubuh. 
Tabel 2. Jenis diatom yang biasa terdapat dalam organ tubuh (Wilianto, 2012)

\begin{tabular}{|l|l|l|}
\hline & Organ Tubuh & Spesies diatom \\
\hline 1. & Paru & $\begin{array}{l}\text { Achnanthes minutissima, Cyclotella cyclopuncta, Fragilaria } \\
\text { brevistriata, Navicula }\end{array}$ \\
\hline 2. & Sum-sum tulang & $\begin{array}{l}\text { Stephanodicus parvus, Navicula, Diatoma and fragments of } \\
\text { Synedra ulna. }\end{array}$ \\
\hline 3. & Hepar & $\begin{array}{l}\text { Achnanthes minutissima, Cocconeis placentula, Fragilaria } \\
\text { ulna var. acus, Navicula lanceolata }\end{array}$ \\
\hline 4. & Ginjal & Achnanthes biasolettiana, N. seminulum \\
\hline 5. & Usus halus & $\begin{array}{l}\text { Achnanthes minutissima, Cyclotella cyclopuncta, } \\
\text { Gomphonema minutum }\end{array}$ \\
\hline 6. & Duodenum & $\begin{array}{l}\text { Asterionella Formosa, Cyclotella comensis, Gomphonema } \\
\text { pumilum dan Nitzscia pura }\end{array}$ \\
\hline
\end{tabular}

Diatom juga dimanfaatkan dalam terapan ilmu paleolimnologi. Paleolimnologi merupakan ilmu yang mempelajari geologi dan perkembangan di perairan tawar. Melalui pendekatan paleolimnologi, informasi fisik, kimia dan biologi yang tersimpan di dalam inti sedimen dapat dimanfaatkan, sehingga diharapkan dapat mengatasi permasalahan kualitas air. Dengan mengetahui kualitas perairan di masa lampau dapat diprediksi kualitas perairan di masa mendatang. Diatom telah diaplikasikan dalam analisis paleoekologi di Everglades National Park Florida Bay, USA (Pyle et al.,1998), Ealden Pond Massachussets USA, Danau Lac Saint Augustine di Quebec City Canada (Pienitz et al., 2006), serta Danau Rawa Pening Indonesia (Soeprobowati \& Hadisusanto, 2009).

Dalam studi paleotsunami, diatom dapat memberikan informasi mengenai sumber sedimen dan perubahan lingkungan seperti yang dilakukan oleh Nentwig et al. (2015) mengenai endapan tsunami di Chili Tengah.
Penelitian tersebut mengungkapkan adanya perubahan lingkungan marsh menjadi 43 dataran banjir (floodplain) yang disebabkan oleh neotektonik selama dan setelah tsunami berdasarkan analisis kelimpahan diatom. Banyak spesies air tawar atau darat sering ditemukan dalam sedimen tsunami disebabkan karena diatom terbawa dan bergabung dengan gelombang tsunami dan melewati zona pesisir ke daratan, sehingga mengalami erosi, transportasi dan terdeposisi dengan taksa habitat terestrial atau air tawar (Dawson et al., 1996). Diatom melimpah di setiap lingkungan darat (freshwater), transisi (brackish), maupun lingkungan laut (marine). Gelombang tsunami mengerosi dan mentransportasi semua material yang dilaluinya dan menghasilkan endapan tsunami termasuk diatom. Tsunami yang melanda Papua New Guinea 1998, menunjukkan bahwa diatom dengan dominasi diatom laut dalam (planktonik), terkandung pula diatom dari darat dan lingkungan transisi (Dawson, 2007). Pencampuran 
kandungan diatom ini dihasilkan melalui proses gelombang tsunami yang mengerosi dan mentransportasi

kandungan diatom yang dilaluinya pada setiap lingkungannya (Gambar 10).

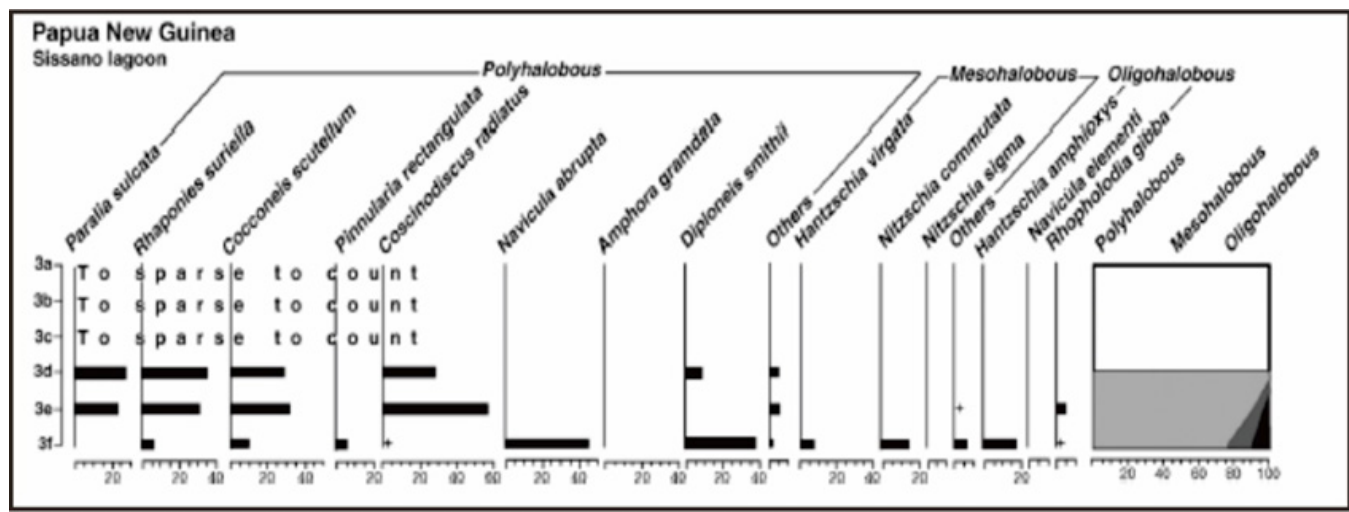

Gambar 10. Diatom pada tsunami Papua 1998. Polyhalobous (freshwater), Mesohalobous (brackish), Oligohalobous (marine) (Dawson, 2007).

Penelitian lain di India 2004, pada endapan tsunami di daerah Phra Thong Island, Thailand (Sawai, et al., 2009). Diatom ditemukan pada endapan pasir sedang dan pasir sangat halus. Pada lapisan endapan tsunami bagian tengah didominasi diatom marine dan pada lapisan endapan tsunami bagian atas mengandung campuran antara spesies diatom freshwater dan brackish serta spesies marine pada bagian paling atas endapan ini (Gambar 11). Hasil ini mengindikasikan perubahan tingkatan energi yang mengendapkan endapan tsunami dan diatom, yaitu selama arus energi tinggi maka hanya mengendapkan endapan pasir berupa diatom bentik. Kemudian setelah arus mengalami penurunan energi, terendapkan material yang lebih halus dan diatom planktonik.

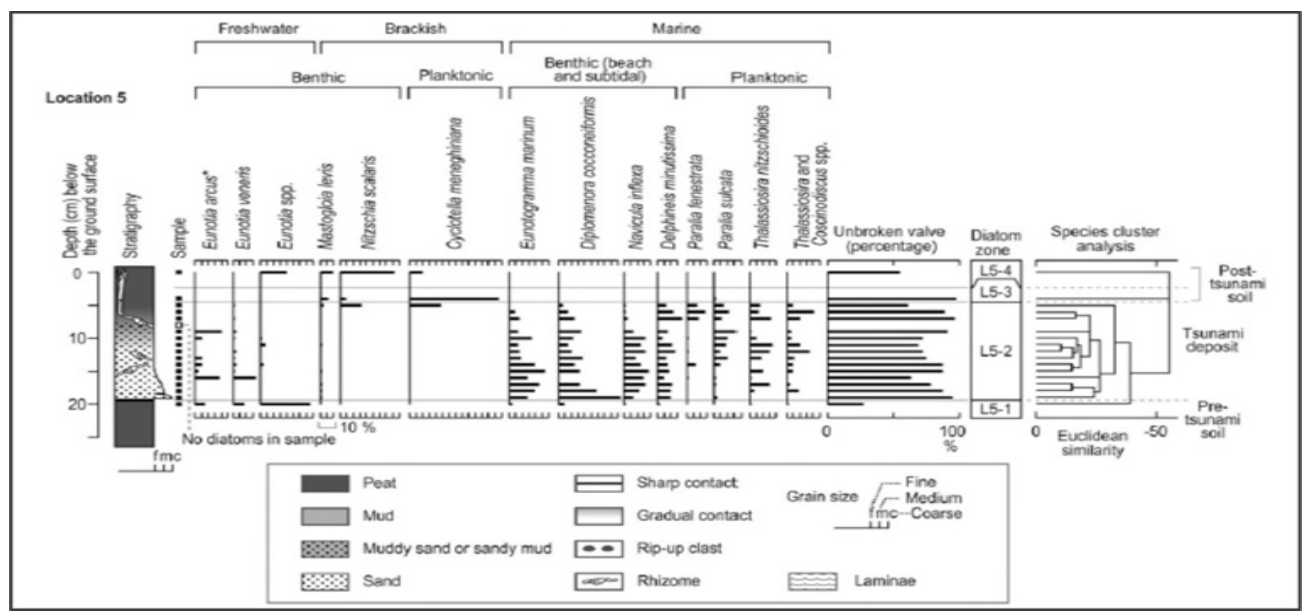

Gambar 11. Diatom pada tsunami Thailand 2004 (Sawai, et al., 2009). 
Kedua penelitian tersebut dapat disimpulkan bahwa diatom pada endapan tsunami merupakan campuran spesies laut, transisi dan darat, menunjukkan bahwa gelombang tsunami mengerosi dan membawa material dari lingkungan tersebut. Dengan mengetahui diatom pada suatu endapan dapat menjelaskan asal lingkungan dan proses sedimentasi baik tsunami maupun proses lainnya. Kandungan diatom pada endapan tsunami akan menunjukkan persentase yang sangat berbeda dengan diatom pada endapan non-tsunami. Hal ini disebabkan pada saat terjadi tsunami diatom akan terendapkan dari semua lingkungan yang dilalui oleh gelombang tsunami.

\section{PENUTUP}

Perkembangan studi diatom baik di dunia sudah sangat signifikan, namun sayangnya di Indonesia masih sangat jarang dilakukan. Diatom memberikan informasi yang berharga dan dipahami denganbaikterutamaberhubungandengan kualitas perairan. Meskipun demikian, informasi dan data yang dihasilkan oleh diatom tidak perlu dibatasi untuk kepentingan kualitas perairan saja. Data diatom dapat digunakan oleh bidang ilmu lain, seperti bidang geologi dan forensik. Di bidang geologi, diatom digunakan untuk merekonstruksi kondisi lingkungan dan ekologi di masa lalu. Selain itu, studi paleotsunami juga menggunakan diatom untuk identifikasi dan membedakan endapan tsunami purba dan non tsunami. Di bidang geosains forensik, diatom digunakan sebagai alat bantu dalam mengotopsi korban tenggelam, dan ini sudah sangat berkembang di luar negeri.

\section{DAFTAR PUSTAKA}

Aiyer, H.P and A.H.M. Reddy. 2013. Initial studies on Diatom Ecology at Kengeri Lake. Advances in Bioresearch 4 (2): 34-37.

Barsanti, L and P. Gualtieri. 2006. Algae Anatomy, Biochemistry, and Biotechnology. Taylor \& Francis Group CRC Press, New York: 301p.

Battarbee, R. W. 1986. Diatomanalysis. In: Berglund B.E. (ed.) Handbook of Holocene palaeoecology and palaeohydrology, J. Wiley \& Sons. Chichester: 527-568.

Bold, H.C and M.J. Wyne. 1985. Introduction to The Algae. Stucture and Reproduction. Prentice-Hall, Inc. Englewood Cliffts, New Jersey United States of America: 720 pp.

Boney, D.D. 1975. Phytoplankton. The Phitman Press, London: 116p.

Cameron, N. G. 2004. The use of diatom analysis in forensic geoscience. In Pye, K. and D. J. Croft (eds.), Forensic Geoscience: Principles, Techniques and Applications. Geological Society, London: 277-280.

Dawson, A.G., S. Shi, S. Dawson, T. Takahashi, and N. Shuto, 1996. Coastal sedimentation associated with the June 2nd and 3rd, 1994 Tsunami in Rajegwesi, Java. Quaternary Science Reviews 15: 901-912. 
Dawson, S. 2007. Diatom Biostratigraphy of Tsunami Deposits, Examples from the 1998 Papua New Guinea Tsunami. Sedimentary Geology 200: 328-335.

Gell, P. A., A. J. Sincock, J. A. Sonneman, M. A. Illman and M. A. Reid. 1999. An Illustrated Key to Common Diatom Genera from Southern Australia. University of Adelaide, Adelaide, New South Wales: $63 \mathrm{p}$.

Harmoko dan Y. Krisnawati. 2018. Mikroalga Divisi Bacillariophyta yang ditemukan di Danau Aur Kabupaten Musi Rawas. Jurnal Biologi Universitas Andalas 6 (1): 3035.

Horton, B. P., S. Boreham and C. Hillier. 2006. The Development and Application of a Diatom-Based Quantitative Reconstruction Technique in Forensic Science. Journal of Forensic Science, 51: 643-650.

Horton, B.P. 2007. Diatoms and forensic science. In Starratt, S. (Ed.). Pond Scum to Carbon Sink: Geological and Environmental Applications of the Diatoms, Paleontological Society Short Course, October 27, 2007. Paleontological Society Papers, Volume 13, the Paleontological Society: 193p.

Kale, A. and B. Karthick. 2015. The Diatoms: Big Significance of
Tiny Glass Houses. Resonance, 20 (10): 919-930.

Kasim, M. 2008. Mengenal Diatom. https://maruf.wordpress.com/ tag/mengenal-diatom/ [online]. Diakses pada tanggal 1 Maret 2019.

Krstic, S., A. Duma, B. Janevska, Z. Levkov, K. Nikolova and M. Noveska. 2002. Diatoms in forensic expertise of drowning - a Macedonian experience. Forensic Science International 127: 198-203.

Mann, D. G. 1999. The Species Concept in Diatoms. Phycologia 38 (6): 437-495.

Murray, R. and J. Tedrow. 1975. Forensic geology: Earth sciences and criminal investigation. Rutgers University Press, New Brunswick, NJ: 240 p.

Murray, R. 2004. Evidence from the Earth: Forensic geology and criminal investigation. Mountain Press, Missoula: 218 p.

Nagy, S. S. 2011. Collecting, Cleaning, Mounting, and Photographing Diatoms. In Seckbach, J. and Kociolek (eds.) The Diatom World. Springer, Netherlands, 1- 18 .

Nentwig, V., S. Tsukamoto, M. Frechen and H. Bahlburg. 2015. Reconstructing the tsunami record in Tirúa, Central Chile beyond the historical record with quartz-based SAR-OSL. 
Quaternary Geochronology 30: 299-305. doi:10.1016/j. quageo.2015.05.020

Nontji, A. 2008. Plankton Laut. LIPI Press. Jakarta: 331 hlm.

Pappas, J.L. and E.F. Stroemer. 2003. Morfometric Comparison of Neotype of Asterionella formosa Hassal. With Asterionella edlundii sp. From Lake Hosgol Mongolia. Diatom 19: 55-65

Peabody, A. J. 1980. Diatoms and drowning--a review. Medicine, Science and the Law 20: 254261.

Peabody, A. J. and R. M. Burgess. 1984. Diatoms in the diagnosis of death by drowning. In D. G. Mann (ed.), Proceeding of the Seventh International Diatom Symposium. Koenigstein, Otto Koeltz: 537-541.

Peabody A. J. 1999. Forensic Science and Diatoms. In Stoermer E. F, Smol J. P (eds). The Diatoms: Applications for the Environmental and Earth Sciences. Cambridge University Press, Cambridge: 413-418.

Pienitz, R., K. Robergem, and W. F. Vincent. 2006. Three Hundred Years Of Human-Induced Change In An Urban Lake: Paleolimnological Analysis Of Lac Saint-Augustin, Quebec City, Canada. Canadian
Journal of Botany 84: 303-320.

Pollanen, M. S. 1997. The diagnostic value of the diatom test for drowning, II. Validity: analysis of diatoms in bone marrow and drowning medium. Journal of Forensic Sciences 42: 286-290.

Pollanen, M. S. 1998. Diatoms and homicide. Forensic Science International 91: 29-34.

Putic, G. 2015. Studi: Plankton, Sumber Oksigen di Bumi [online]. https://www.voaindonesia. com/a/studi-plankton-sumberoksigen-di-bumi/2792079. html. Diakses pada tanggal 1 Maret 2019.

Pye, K. and D. J. Croft. 2004. Forensic Geoscience: Principles, Techniques and Applications. Geological Society, London: 232-318 p.

Pyle, L., R. Sherri, Cooper, and J. K. Huvane. 1998. Diatom paleoecology Pass Key core 37, Everglades National Park, Florida Bay. Report USGS Numbered Series 98-522. U.S. Geological Survey: 37 p. DOI: 10.3133/ofr98522

Roito, M., Y.I. Siregar dan Mubarak. 2014. Analisis Struktur Komunitas Diatom Planktonik Di Perairan Pulau Topang Kabupaten Kepulauan Meranti Provinsi Riau. Jurnal Perikanan dan Kelautan 19 (2): 22-32 
Round, F. E., R. M. Crawford and Mann, D.G. 1990. The Diatoms: Biology and Morphology of the Genera. Cambridge University Press, Cambridge: 747 pp.

Ruffell, A., and J. Mckinley. 2005. Forensic Geoscience: applications of geology, geomorphology \& geophysics to criminal investigations. Earth Science Reviews 69: 235247.

Ruffell, A. 2006. Forensic Geoscience. Geology Today 22: 68-70.

Saferstein, R. 2001. Criminalistics: An Introduction to Forensic Science. New Jersey, Prentice Hall. Upper Saddle River: 434 p.

Sari, R.M., S. Ngabekti, dan F. P. Martin. 2013. Keanekaragaman Fitoplankton di Aliran Sumber Air Panas Condrodimuko Gedongsongo Kabupaten Semarang. Unnes Journal of Life Science 2 (1): 9 - 15.

Sawai, Y., K. Jankaew, M. E. Martin, A. Prendergast, M. Choowong, and T. Charoentitirat. 2009. Diatom assemblages in tsunami deposits associated with the 2004 Indian Ocean tsunami at Phra Thong Island, Thailand. Marine Micropaleontology 73:70-79. https://doi.org/10.1016/j. marmicro.2009.07.003.
Siver F. A, W. D. Lord and D. J. McCarthy. 1994. Forensic limnology: The use of fresh water community ecology to link suspects to an aquatic crime scene in southern New England. Journal of Forensic Sciences 39: 847-853.

Siregar, S.H dan K.S. Telaumbanua. 2010. Variasi diatom epifitik (Bacillariophyceae) pada batang dan Pneumatophore bakau avicennia sp. di kawasan Pelabuhan Tanjung Buton, Provinsi Riau. Ilmu Lingkungan 1 (4): 11-24.

Soeprobowati, T.R. dan S. Hadisusanto. 2009. Diatom dan Paleolimnologi: Studi Komparasi Perjalanan Sejarah Danau Lac Saint-Augustine Quebeq-City, Canada dan Danau Rawa Pening Indonesia. Biota 14 (1): 60-68.

Smol, J. P. 1990. Are we building enough bridges between paleolimnology and aquatic ecology? Hydrobiologia, 214: 201-206.

Taylor, J.C., W.R. Harding and C.G.M. Archibald. 2007. An Illustrated Guide to Some Common Diatom Species from South Africa. Water Research Commission, Pretoria: 225 p.

Weckstrom, J. and A. Korhola, 2001. Patterns in the distribution, composition, and diversity of diatom assemblages in 
relation to ecoclimatic factors in Arctic Lapland. Journal of Biogeography 28: 31-45.

White, P. 2004. Crime Scene to Court: The Essentials of Forensic Science. The Royal Society of Chemistry, Cambridge: $451 \mathrm{p}$.

Wickstead, J.H. 1965. An introduction to the study of tropical plankton. Hutchonson Tropical Monograph, London: 160p.
Wilianto, W. 2012. Pemeriksaan Diatom pada Korban Diduga Tenggelam (Review). Jurnal Kedokteran Forensik Indonesia 14 (3): 39-46.

Yuliana. 2007. Struktur komunitas dan kelimpahan fitoplankton dalam kaitannya dengan parameter fisika-kimia perairan di Danau Laguna Ternate, Maluku Utara. Jurnal Protein 14 (1): 85-92. 